Original Research Paper

\title{
Exogenous Progesterone for Offspring Sex Ratio Manipulation in Arabic Chickens (Gallus turcicus) Leading to Increasing Female Chicks Proportion
}

\author{
${ }^{1}$ Iswati, ${ }^{2}$ Muhammad Halim Natsir, ${ }^{2}$ Gatot Ciptadi and ${ }^{2}$ Trinil Susilawati \\ ${ }^{1}$ Department of Animal Husbandry, Agricultural Development Polytechnic, Malang, Indonesia \\ ${ }^{2}$ Faculty of Animal Science, Brawijaya University, Malang, Indonesia
}

\author{
Article history \\ Received: 04-11-2021 \\ Revised: $16-02-2021$ \\ Accepted: 17-02-2021 \\ Corresponding Author \\ Trinil Susilawati \\ Faculty of Animal Science, \\ Brawijaya University, Malang, \\ Indonesia \\ Email: tsusilawati@ub.ac.id
}

\begin{abstract}
Female birds of egg-laying hens are more valuable than males, because males bird have no commercial value. The opportunity to manipulate offspring sex ratio in poultry has been observed in female birds; hence, female birds have heterogametic ZW chromosomes. High progesterone concentration $2-5 \mathrm{~h}$ before ovulation is thought to affect the segregation of female sex chromosomes as the basis for determining the sex of offspring. This study aimed to investigate the effect of progesterone induction in Arabic hens, which was conducted $5 \mathrm{~h}$ before ovulation, along with the time of the first meiosis; therefore, segregation of sex chromosomes leading to an increase in female offspring. The study utilized on 60 Arabic hens divided into three treatment groups: Without injection $\left(\mathrm{P}_{0}\right)$, progesterone injection $1 \mathrm{mg} / \mathrm{hen},\left(\mathrm{P}_{1}\right)$, progesterone injection $2 \mathrm{mg} / \mathrm{hen}$ $\left(\mathrm{P}_{2}\right)$. The results showed that the percentage of female offspring at $\mathrm{P}_{0}$ and $\mathrm{P}_{1}$ was 54.74 and $53.33 \%$, respectively, while $\mathrm{P}_{2}$ hens resulted in $62.92 \%$ females, the highest female offspring rate than the other groups. Chi-square analysis of sex ratio showed that $\mathrm{P}_{0}$ and $\mathrm{P}_{1}$ hens had no significant effect $(\mathrm{P}>0.05)$ while $\mathrm{P}_{2}$ hens being significant $(\mathrm{P}<0.05)$ from the expected sex ratio (50:50). Progesterone concentration of hens produced female offspring in the $\mathrm{P}_{2}$ group was $7.15 \mathrm{ng} / \mathrm{ml}$ being highly significant $(\mathrm{P}<0.05)$ than that found in the hens produced male offspring $(4.53 \mathrm{ng} / \mathrm{ml})$. Progesterone $5 \mathrm{~h}$ preceding ovulation in the Arabic hens with a $2 \mathrm{mg} / \mathrm{hen}$ dose can increase the proportion of female offspring; therefore, an opportunity for sex ratio manipulation in Arabic chickens.
\end{abstract}

Keywords: Arabic Chicken, Progesterone, Sex Chromosome, Sex Ratio Manipulation

\section{Introduction}

Arabic chickens are very popular among farmers in Indonesia as one of the local laying hens; they have a high productivity of eggs than other native chickens, with no nestling traits and are more resistant to disease. There are two types of Arabic chicken: Silver Arabic chicken and Gold Arabic chicken. Gold Arabic chickens have better egg production than Silvers, while Gold Arabic chickens are preferred by the local layer chicken industry (Indra et al., 2013).

The chicken farming industry requires the sex of the chicken, according to business, to produce eggs or meat (Susilawati, 2014). The Arabic chicken farm industry certainly needs more females as egg producers.
The Arabic chicken industry's major problem is how to increase female offspring higher than males because males do not give economic benefits. This problem makes farmers look for an avenue to manipulate the sex ratio of hatched chicks, minimizing Day Old Chick (DOC) with unwanted sex. The practical implications are essential for commercial poultry farming as they can find ways to reduce the male chicks in the production of laying hens culled after hatching (Aslam et al., 2013; Krautwald-Junghanns et al., 2018). Manipulation of the sex ratio of chicken breeds aims to increase the number of offspring of one sex in a population and suppress the acquisition of unnecessary sex (Afriani et al., 2011).

Sex ratio manipulation in chickens usually bases on the principle of sex determination and differentiation. 
The sex chromosome in male chickens is $\mathrm{ZZ}$, while in hens is $\mathrm{ZW}$; the sex of the offspring is influenced by the hen chromosome (Hens, 2001). The sex ratio manipulation strategy in poultry began to develop with biological evolution that the hens were able to allocate one of its sex chromosomes $(\mathrm{Z}$ or $\mathrm{W})$ to determine the sex of the offspring because heterogametic existed in females. (Smith, 2007; Kuroiwa, 2017; Navara, 2018). In chickens and quails, the offspring sex is determined $2-4 \mathrm{~h}$ before ovulation during the first meiotic division, when one sex chromosome remains in the oocyte and separates it into the polar body (Pinson et al., 2011a). The factors that influence the allocation of the sex ratio of chicks is maternal hormones. Maternal hormones are expected biased offspring sex ratio (not following the 1:1 proportion), a phenomenon known as sex ratio manipulation (Alonso-Alvarez, 2006; Gam and Navara, 2016).

Maternal steroid hormones are predicted to influence the sex of eggs during oogenesis, especially meiosis I. When $\mathrm{Z}$ and $\mathrm{W}$ chromosome segregation occurs, one of the chromosomes $(\mathrm{Z}$ or $\mathrm{W})$ remains in the oocyte and the other is in the polar body (Pinson et al., 2011b; Navara, 2018). The progesterone is predicted to have significant effect in meiosis I (Correa et al., 2005). Progesterone is the primary steroid produced by birds' pre ovulatory follicles during meiosis I about 2 to $5 \mathrm{~h}$ before ovulation, which is a critical time for genetic sex determination. Correa et al. (2005) investigated the injection of high doses $(2 \mathrm{mg})$ of progesterone as an exogenous hormone to increase hormone levels. Progesterone in estimated meiosis has produced a primary sex ratio of $75 \%$ female offspring in white leghorn layer chickens (Gallus gallus domesticus).

This is the first study; until this study was conducted, there had not been any reported attempts to regulate the sex ratio of offspring in Arabic chickens leading to the female sex as egg producers. Therefore, the current study aims to determine whether the administration of progesterone in Arabic hens, at $5 \mathrm{~h}$ before expected ovulation, can change offspring sex as an opportunity for manipulation of the sex ratio towards females, which are more profitable for the poultry industry.

\section{Materials and Methods}

\section{Experimental Animals}

This study used 60 Arabic Gold Females (Gallus turcicus) obtained from "Mitra Ternak Juara Group" farm in Probolinggo, Indonesia. The chicken is 28 weeks old, placed in individual cages. Mating chickens with Artificial Insemination (AI) twice a week (Habibullah et al., 2015; Pinson et al., 2011a) with semen collected from three male Arabic Gold roosters to keep egg fertility. All chickens were fed on a commercial chicken feed. It contained 2500-2700 Kcal $/ \mathrm{kg}$ metabolizable energy, $14-16 \%$ protein, $4-7 \%$ crude fat, $5-7 \%$ crude fiber and 5$7 \%$ ash; and drinking water $a d-l i b$.

\section{Injection Time}

The study was conducted experimentally with a Completely Randomized Design (CRD); chickens were randomly divided into three treatments and ten replicates, each replicates consisting of two chickens $\left(\mathrm{P}_{0}\right.$ : Control without injection; $\mathrm{P}_{1}$ : Progesterone injection $1 \mathrm{mg} / \mathrm{hen}, \mathrm{P}_{2}$ : Progesterone injection 2 $\mathrm{mg} / \mathrm{hen}$ ). The total number of chickens per group is 20 hens; according to a study simulation by (Wilson and Hardy, 2002). This study utilized Progesterone hormone P0478-5G (Production: Tokyo Chemical Industry (TCI) Co., LTD) is dissolved in $0.5 \mathrm{ml}$ of sesame oil and injected subcutaneously $5 \mathrm{~h}$ before ovulation predictions at the next oviposition. The estimated egg-laying time was calculated from observations of the previous day's oviposition. The injection was carried out twice a week for four weeks (28-31week of chick age) according to each chicken's egg-laying cycle. The schedule of progesterone injection is shown in Fig. 1.

The same schedule was reported by (Pinson et al., 2011b), with different hormonal treatments. The egglaying point was observed every about $2 \mathrm{~h}$ on the first day as the first egg oviposition. On the second day, a blood sample was collected and injection of the progesterone was performed at $5 \mathrm{~h}$ preceding the next expected ovulation. The injection time is the prediction time of meiosis I (segregation of $\mathrm{Z}$ and $\mathrm{W}$ chromosomes) until about $2 \mathrm{~h}$ before the target egg ovulation; the second day, the oviposition time was also recorded. The third day or one day after injection was the target egg collection due to the progesterone injection, about 24-26 h from the second egg oviposition. At the oviposition, time was recorded to ensure that the target egg laid according to the predicted time. Hens that ware not laying at the expected time, continued for the laying cycle and the next injection period; therefore, each group received eight injections for four weeks. Blood sampling was carried out $2 \mathrm{~h}$ after the hormone injection assuming a critical period to increase the progesterone level 2-3 $\mathrm{h}$ before the estimated ovulation (Correa et al., 2005).

\section{Hatching Eggs}

The targeted eggs were collected from each hen were stored at $18^{\circ} \mathrm{C}$ before entering the hatching process. According to the expected point of oviposition time, targeted eggs hatched at a temperature of $99.5^{\circ} \mathrm{F}$ and a humidity of 55-60\% (Mohan et al., 2015). Seven days of hatching, candling was carried out to determine the fertility of the hatching eggs, infertile eggs were removed from the hatching machine and fertile eggs are continued to hatch (Abdellatif, 2001; Al-Maksousi et al., 2019). 


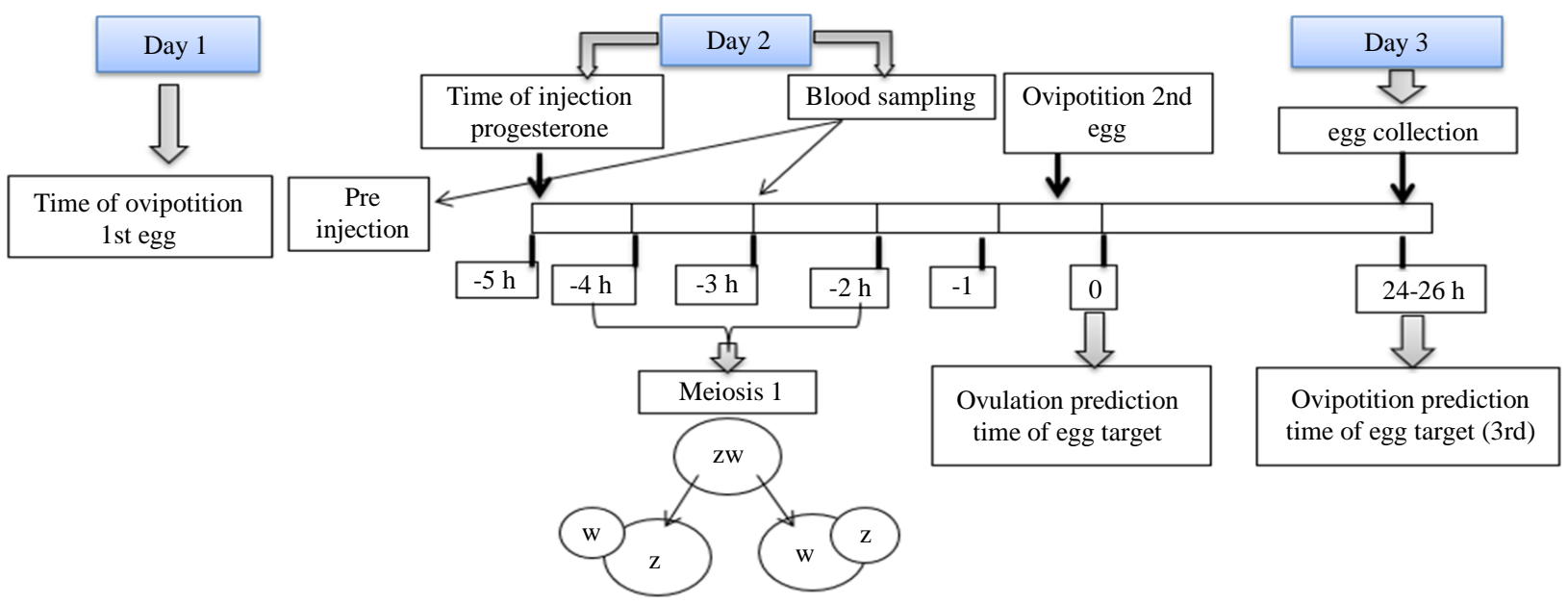

Fig. 1: Schematic diagram of a one-time Progesterone injection $5 \mathrm{~h}$ before estimated ovulation

\section{Sex Ratio}

The newly hatched chicks reared for four weeks of age to confirm sex using secondary sex signs (Tamzil et al., 2018). The sex ratio in this study was the secondary sex ratio which was performed at a particular time after hatching (in this study 4 weeks) until the secondary sex sign appeared (Al-Maksousi et al., 2019).

\section{Blood Progesterone Determination}

Blood samples collected from the brachial vein $2 \mathrm{~h}$ after injection to verify the Progesterone surge in the treatment group chickens. Progesterone concentration in the blood was determined using the Enzyme-Linked Immunosorbent Assay (ELISA) method. Blood serum was obtained by fresh blood clotting for 10-20 min at room temperature, then pipetting the clear liquid above the sediment (serum) and in a centrifuge at 2000-3000 RPM for $20 \mathrm{~min}$; the ELISA test procedure is following the Chicken Progesterone ELISA Kit, (Bioassay Technology Laboratory; Cat.No E0053Ch). The standard curve range was $0.05 \mathrm{ng} / \mathrm{ml}-10 \mathrm{ng} / \mathrm{ml}$ and the test sensitivity was $0.019 \mathrm{ng} / \mathrm{ml}$. Readings of results on the Bio-rad ELISA Reader with absorbance measured at $450 \mathrm{~nm}$ (Mohammadi and Ansari-Pirsaraei, 2014; Al-Maksousi et al., 2019).

\section{Statistical Analyses}

The sex ratio is the ratio of female and male offspring percentage from each treatment. The sex ratio of chicks for each treatment was analyzed by the chi-square ( $\mathrm{X}^{2}$-test) compared to the sex ratio percentage of 50:50. The concentration of progesterone among treatment groups were analyzed by Analysis Of Variance (ANOVA) with a confidence level of $95 \%(\mathrm{P}<0.05)$. If there is a significant difference, Duncan's Multiple Range Test
(DMRT) was applied. The t-test comparison of progesterone concentrations between the henproducing male and female chicks was analyzed (Correa et al., 2005).

\section{Results}

\section{The Target Eggs}

Treatment of progesterone injection in Arabic hen resulted in varying target egg numbers. The average target eggs of the three treatment groups were $77.71 \%$, there were $13.13 \%$ hens with oviposition but not at the expected time and $9.17 \%$ of the hens not laying or had no oviposition. The data of the target eggs in each treatment group is shown in Table 1.

The target eggs based on the expected egg-laying time, were entered the hatching machine. In the evaluating of hatching, there were infertile eggs, die during hatching and not hatching. A newly hatched one day-old chick reared for up to 4 weeks in order to sex identification and sex ratio determination. The data of the hatching egg and the sex ratio of Arabic chicks is shown in Table 2 .

\section{Secondary Sex Signs in Arabic Chicken}

Arabic chicks show secondary sex signs phenotypically: Male chicks comb appear thicker and red, while female chicks do not showcomb growth or thincomb, which seen in Fig. 2.

The result of the analysis of the Progesterone concentration of the Arabic hen is shown in Table 3.

The $T$-test analysis of the progesterone concentration of hens produced male and female chicks of the three treatment groups, as shown in Fig. 3. 


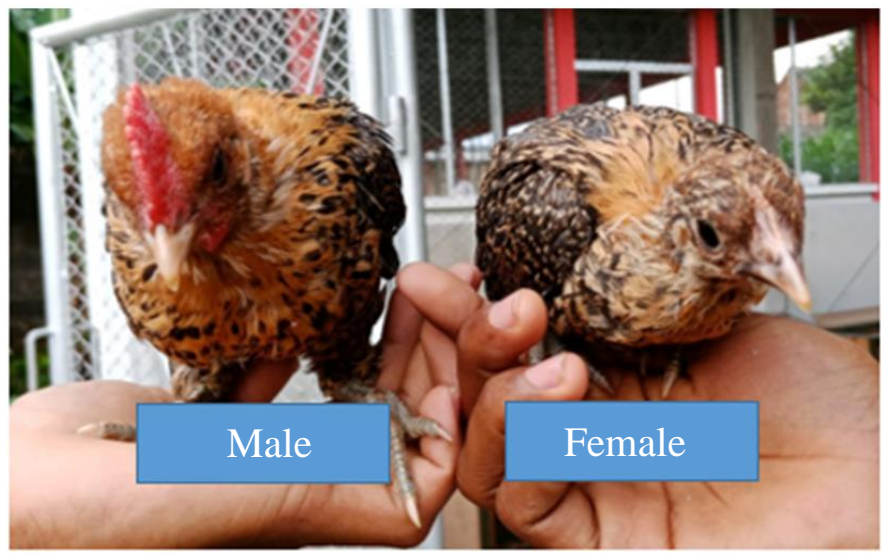

Fig. 2: The differences in the secondary sex signs of 4 weeks old Arabic Gold chicks. Male Arabic chicks show red and thicker combs, while female Arabic chicks have thinner combs

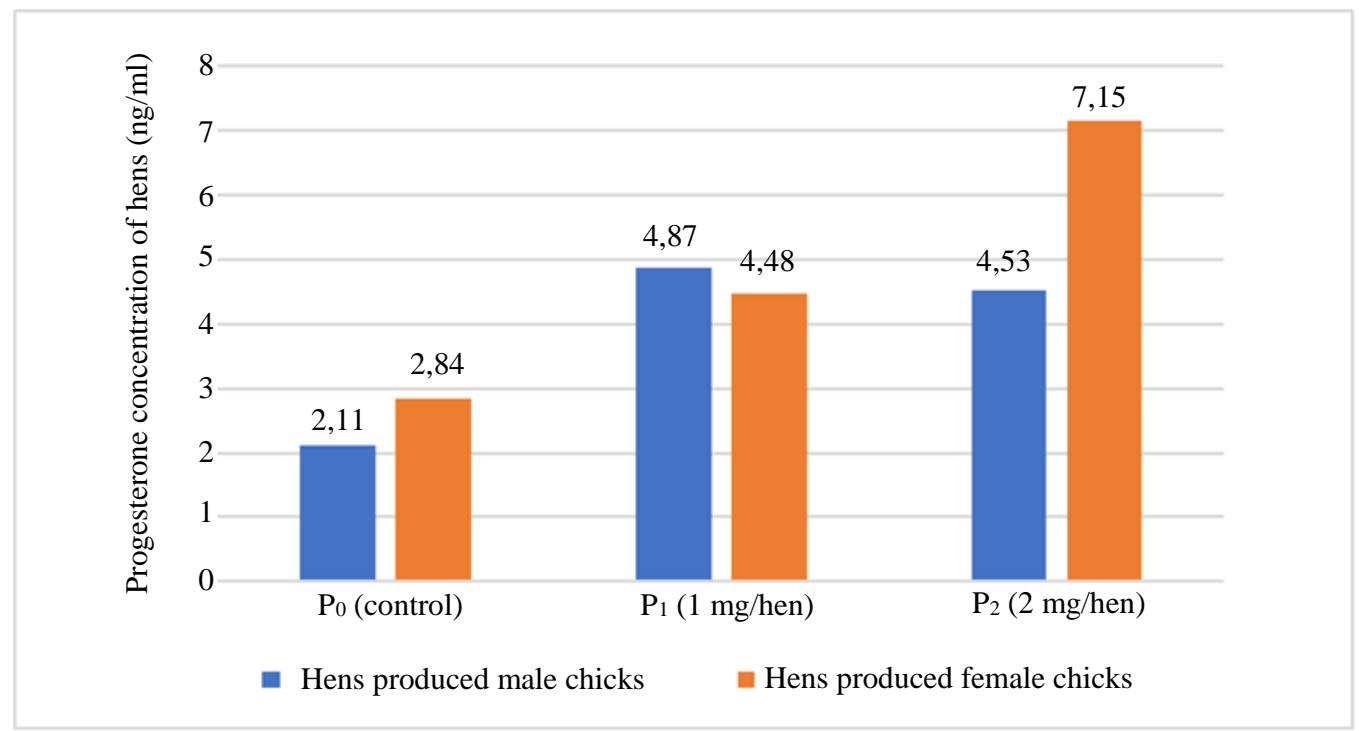

Fig. 3: Blood progesterone concentration in the Arabic hens based on produced offspring sex: in the $P_{0}$ and $P_{1}$ group are not significant; while in $\mathrm{P}_{2}$ group is significant $(\mathrm{P}<0.05)$

Table 1: Target egg data after progesterone administration

\begin{tabular}{llll}
\hline & Target eggs & & \\
& & & \\
Treatment & Presentation of expectation $(\%)$ & Laying not at the target time (\%) & No oviposition $(\%)$ \\
\hline $\mathrm{P}_{0}$ & $76.88 \pm 10.67$ & $14.37 \pm 6.42$ & $8.75 \pm 3.96$ \\
$\mathrm{P}_{1}$ & $80.63 \pm 7.28$ & $11.25 \pm 5.27$ & $8.12 \pm 3.70$ \\
$\mathrm{P}_{2}$ & $75.62 \pm 10.15$ & $15.00 \pm 6.79$ & $9.38 \pm 4.24$ \\
\hline
\end{tabular}

$\mathrm{P}_{0}$ : Control, $\mathrm{P}_{1}$ : Progesterone injection $1 \mathrm{mg}, \mathrm{P}_{2}$ : Progesterone injection $2 \mathrm{mg}$

The target eggs are eggs on day 1 after Progesterone injection

Table 2: Effect of progesterone administration on number of hatching eggs, hatching percentage and sex ratio of chicks

\begin{tabular}{lllllllll}
\hline Treatment & $\begin{array}{l}\text { No. hatching } \\
\text { eggs }\end{array}$ & $\begin{array}{l}\text { Infertile } \\
\text { eggs }(\%)\end{array}$ & $\begin{array}{l}\text { Mortality of embryos } \\
\text { and not hatching (\%) }\end{array}$ & $\begin{array}{l}\text { No. chicks } \\
\text { hatched }\end{array}$ & Female (\%) & Male (\%) & $\begin{array}{l}\text { Sex ratio } \\
\text { (Female: Male) }\end{array}$ & $\begin{array}{l}\text { value } X^{2} \\
\text { (T-test) }\end{array}$ \\
\hline $\mathrm{P}_{0}$ & 123 & 11.78 & 12.04 & 95 & 54.74 & 45.26 & $1.2: 1$ & 0.72 \\
$\mathrm{P}_{1}$ & 129 & 16.38 & 15.89 & 90 & 53.33 & 46.67 & $1.1: 1$ & 0.32 \\
$\mathrm{P}_{2}$ & 121 & 11.94 & 15.24 & 89 & 62.92 & 37.08 & $1.7: 1$ & $6.17 *$ \\
\hline
\end{tabular}

* Significant $(\mathrm{P}<0.05)$ 
Table 3: Hen's blood progesterone concentration after progesterone induction

\begin{tabular}{ll} 
Treatment & Progesterone concentration $($ Mean \pm SEM) \\
\hline $\mathrm{P}_{0}$ & $2.47 \pm 0.41^{\mathrm{a}}$ \\
$\mathrm{P}_{1}$ & $4.67 \pm 0.52^{\mathrm{b}}$ \\
$\mathrm{P}_{2}$ & $5.84 \pm 0.57^{\mathrm{b}}$ \\
\hline
\end{tabular}

Description: Different superscript in the same column indicate significant differences $(\mathrm{P}<0.05)$

\section{Discussion}

\section{The Target Eggs After Progesterone Induction}

Table 1 shows different target eggs among treatments. The difference of target eggs is due to the effect of the egg-laying cycle (clutch) of hen, which directly affects daily egg production. Egg per clutch is influenced by hen's genetics (Idowu et al., 2019). Current research shows that the target egg was relatively high at peak production in Arabic chickens. This study indicated that $\mathrm{P}_{2}$ treatment had a higher number of nonoviposition than $\mathrm{P}_{1}$ and $\mathrm{P}_{0}$. This is related to Progesterone's effect on egg production, which causes a decrease in egg production (Zaghari et al., 2009). $\mathrm{P}_{2}$ shows the highest number of oviposition beyond the expected target period. These eggs were not included in the analysis. Exogenous Progesterone injection affects ovulation and oviposition, not at the expected period. The earlier oviposition time was probably due to Progesterone, causing a surge in Luteinizing Hormone; therefore, ovulation was earlier. The slower oviposition than the expected period was perhaps attributed to the eggs restrained for a longer duration in the oviduct, especially in the uterus. This reason refers to the results of (Bacon and Liu, 2004) that high Progesterone levels can inhibit uterine smooth muscle contraction from locking in oviposition and retaining eggs for a longer time in the shell gland (uterus).

\section{The Sex Ratio of Chicks}

Table 2 shows that infertile eggs and dead embryos were not included in the sex ratio data analysis. An incision was made in the chicks' abdomen, which died during the rearing period (up to 4 weeks) for gonadal observation and then the sex was identified. The dead chicks during rearing in each group were $8\left(\mathrm{P}_{0}\right), 6\left(\mathrm{P}_{1}\right)$ and $3\left(\mathrm{P}_{2}\right)$. The sex ratio analysis counted from live chicks until the 4 th week and dead chicks whose sex was identified (Al-Maksousi et al., 2019).

Table 2 shows that the treatment produced a percentage of female offspring at $\mathrm{P}_{0}, \mathrm{P}_{1}$ and $\mathrm{P}_{2}$, namely $54.74,53.33$ and $62.92 \%$. This result different from the work of (Correa et al., 2005), who obtained $75 \%$ female offspring of the primary sex ratio when Progesterone was administered ( $2 \mathrm{mg} / \mathrm{hen})$ in laying hens. The difference in this study's results was assumed to be due to the sex ratio in the current research did not include embryos that died at hatching because the secondary sex ratio performed at four weeks of age chicks was not the embryonic sex ratio or primary sex ratio. The sexspecific mortality was not included in the analysis; whether more male or female embryos died during hatching, only chicks that hatched were included in the sex ratio analysis. The injection method also was thought to affect the results. Different injection times can be involved in different ways, as in the study of (Correa et al., 2005; Pinson et al., 2011a), who did hormone induction with a single dose. In contrast, the present study was carried out with repeated doses in the next egg-laying cycle.

The sex ratio of offspring in birds generally follows the 50:50 (1:1) hypothesis. Sex ratio manipulation with the hens' hormonal treatment was expected to affect the sex ratio of the offspring as a bias sex ratio that deviates from the expected sex ratio (Pike and Petrie, 2005). The sex ratio of female to male offspring was tested by chisquare ( $\mathrm{X}^{2}$ test). It has been shown that in treatment $\mathrm{P} 0$, the sex ratio of 1.2: 1 and 1.1: 1 in $\mathrm{P}_{1}$ were not significantly different from hypothesis (1: 1). However, $\mathrm{P}_{2}$ showed a sex ratio of 1.7: 1 differing significantly from the sex ratio of $1: 1$, with a value of $\mathrm{X}^{2}=6.71$ greater than $\mathrm{X}^{2}$ table $(0.05)=3.84$ (Table 2 ).

Based on this study's results, the increase in female offspring's ratio by $2 \mathrm{mg} / \mathrm{hens}$ of progesterone induction was expected to provide practical applications for layer chicken breeders. Increasing the percentage of female offspring compared to males has a vital role in reducing maintenance resources in the poultry industry. Male offspring from laying hens are less economically beneficial if raised as producers of meat. It also reduces the culling of male chicks after hatching, which often creates animal welfare conflicts in laying hens (Galli et al., 2016).

Determination of the sex ratio of Arabic chicks was not carried out when DOC hatched because the newly hatched Arabic chickens were almost monomorphic, could not be distinguished between male and female and according to previous studies, sexing using feather sexing on the freshly hatched Arabic chicks only had an accuracy of $80.47 \%$ (Iswati et al., 2020). Sexing of Arabic chicks was performed at four weeks of age (Fig. 2), which had shown secondary sex signs as the study of (Al-Maksousi et al., 2019), who analyzed the sex ratio of Iraqi chickens at four weeks of age. 


\section{Progesterone Concentration in Blood}

Progesterone concentration in hens was measured at $2 \mathrm{~h}$ after hormone injection, or it coincides with $3 \mathrm{~h}$ before the estimated time of ovulation. This confirms that maternal hormones play a role in the first meiosis by influencing the segregation of non-random chromosomes segregation. According to (Correa et al., 2005), high Progesterone during meiosis is a mechanism for sex manipulation of offspring in bias the primary sex ratio.

Table 3 shows that the concentration of the hormone progesterone in the blood showed a significant difference $(\mathrm{P}<0.05)$ between the treatment group and the control group $\left(\mathrm{P}_{0}=2.47 \pm 0.41 \mathrm{ng} / \mathrm{ml}\right)$. Progesterone concentrations were $4.67 \pm 0.52$ and $5.84 \pm 0.57 \mathrm{ng} / \mathrm{ml}$ in $\mathrm{P}_{1}$ and $\mathrm{P}_{2}$, respectively with non-significant difference $(\mathrm{P}>0.05)$. When associated with the sex ratio of chicks produced, group P2 resulted in higher female offspring having higher progesterone concentrations.

The control group $\left(\mathrm{P}_{0}\right)$ which assumed as a physiological condition showing progesterone levels 2-3 $\mathrm{h}$ before ovulation, where the chromosome segregation process occurs. Physiologically, the progesterone concentration in Arabic chickens in this study was in the normal range of Progesterone concentrations in poultry is $2-3 \mathrm{ng} / \mathrm{ml}$ (Reece, 2009). The physiological level does not cause a biased sex ratio.

Even though the progesterone concentration of group $\mathrm{P}_{1}$ was higher than control $\left(\mathrm{P}_{0}\right)$, it did not cause a significant sex ratio bias towards the number of female offspring, because the progesterone concentration at the $\mathrm{P}_{1}$ level has not made the random sex allocation lead to the female sex. Progesterone concentration of the $\mathrm{P}_{2}$ group exhibited the highest value. It makes the sex ratio significantly different $(\mathrm{P}<0.05)$ from the expected sex ratio of $1: 1$, or there was a biased sex ratio towards females and a decrease in the proportion of male offspring. This finding follows the study by (Correa et al., 2005), who stated that layer hens have higher Progesterone levels and a decreased proportion of male offspring.

Progesterone concentration of hens, which produced male and female chicks of the three treatment groups, showed that only the $\mathrm{P}_{2}$ group resulted in a significant difference $(\mathrm{P}<0.05)$ (Fig. 3). Hens of the $\mathrm{P}_{2}$ treatment group that produced female offspring showed a higher progesterone concentration than the hens with male offspring $(\mathrm{P}<0.05)$. This is following (Correa et al., 2005) study, who found that hens laid female eggs had a higher concentration of Progesterone than hens laid male eggs. Among other treatments, progesterone concentration between hens that produced male and female chicks was not different. Moreover, it has been shown that the relatively low progesterone levels tested in the present study have not been able to bias sex toward females.

\section{Conclusion}

Treatment of progesterone injection in hens resulted in a higher blood concentration of Progesterone than the untreated group. Meanwhile, Progesterone's administration in the Arabic hens at a dose of $2 \mathrm{mg} /$ hen caused an increase in the proportion of female chicks, therefore becoming an opportunity for manipulation of the sex ratio of the Arabic chicks after hatching.

\section{Acknowledgment}

Special thanks to the Head of the Agricultural Human Resources Counseling and Development Agency, the Ministry of Agriculture as the scholarship provider, the Director of the Agricultural Development Polytechnic of Malang, who has granted permission to use the research facilities.

\section{Funding Information}

Agricultural Human Resources Counseling and Development Agency, the Ministry of Agriculture Agricultural Human Resources Counseling and Development Agency, the Ministry of Agriculture as the funders of this research.

\section{Author's Contributions}

Iswati and Trinil Susilawati: Designed and conducting the experiment and writing the manuscript.

Muhammad Halim Natsir and Gatot Ciptadi: Analyzed the data and participated in the revision of the document.

\section{Ethics}

This study was approved by the Animal Ethics of Brawijaya University with the number 001-KEP-UB-2020 and declared to fulfill the study's ethical feasibility. All procedures and maintenance of chickens are by institutional guidelines for the use of animals in research.

\section{References}

Abdellatif, M. A. (2001). Sexing on down and feather colour in the Dandarawi Egyptian breed. British Poultry Science, 42(3), 327-332. https://doi.org/10.1080/00071660120055287

Afriani, T., Udin, Z., Jaswandi, D., Asmairicen, S. (2011). Pengaruh Waktu Pelapisan Spermatozoa Sapi Pada Media TALP yang Disuplementasi bovine serum albumin (BSA) Terhadap Jenis Kelamin Embrio In vitro. Jurnal Peternakan Indonesia, $13 \quad$ (2); 141-148. https://doi.org/10.25077/jpi.13.2.141-148.2011 
Al-Maksousi, S. K., Al-Hayani, W. K., \& Hussein, F. M. (2019). Effect of the level of corticosteron hormone in the blood of local iraqi chicken mothers on the sex ratio of the produced offsprings. Plant Archives, 19(2), 1411-1415.

Alonso-Alvarez, C. (2006). Manipulation of primary sex-ratio: an updated review. Avian and Poultry Biology Reviews, 17(1), https://doi.org/10.3184/147020606783437930

Aslam, M. A., Hulst, M., Hoving-Bolink, R. A., Smits, M. A., de Vries, B., Weites, I., ... \& Woelders, H. (2013). Yolk concentrations of hormones and glucose and egg weight and egg dimensions in unincubated chicken eggs, in relation to egg sex and hen body weight. General and Comparative Endocrinology, 187, 15-22. https://doi.org/10.1016/j.ygcen.2013.02.045

Bacon, W. L., \& Liu, H. K. (2004). Progesterone injection and egg production in turkey hens. Biology of Reproduction, 71(3), 878-886. https://doi.org/10.1095/biolreprod.104.027672

Correa, S. M., Adkins-Regan, E., \& Johnson, P. A. (2005). High progesterone during avian meiosis biases sex ratios toward females. Biology Letters, 1(2), 215-218.

Galli, R., Preusse, G., Uckermann, O., Bartels, T., Krautwald-Junghanns, M. E., Koch, E., \& Steiner, G. (2016). In ovo sexing of domestic chicken eggs by Raman spectroscopy. Analytical Chemistry, 88(17), 8657-8663. https://doi.org/10.1021/acs.analchem.6b01868

Gam, A. E., \& Navara, K. J. (2016). Endogenous corticosterone elevations five hours prior to ovulation do not influence offspring sex ratios in Zebra Finches. Avian Biology Research, 9(3), 131-138. https://doi.org/10.3184/175815516X14495923605779

Habibullah, M., Hashem, M. A., Rana, M. S., \& Islam, M. H. (2015). Effect of Artificial Insemination on different production parameter in Hubbard classic broiler parent stock. Journal of the Bangladesh Agricultural University, 13(1), 71-77. https://doi.org/10.3329/jbau.v13i1.28720

Hens, E. H. (2001). cocks and avian sex determination. A quest for genes on $\mathrm{Z}$ or W. EMBO Reports, 2(3), 192196. https://doi.org/10.1093/embo-reports/kve050

Idowu, P. A., Mpayipheli, M., \& Muchenje, V. (2019). A Survey Study on Productive and Reproductive Performance of Indigenous Poultry. https://doi.org/10.3844/ajavsp.2019.33.39

Indra, G. K., Achmanu, A., \& Nurgiartiningsih, A. (2013). Performans produksi ayam Arab (Gallus turcicus) berdasarkan warna bulu. Ternak Tropika Journal of Tropical Animal Production, 14(1), 8-14.

Iswati, M. Natsir, H., Ciptadi, G., \& Susilawati, T. (2020). Sexing on a Day-Old Chick of Gold Arabic Chicken (Gallus turcicus) Using Feather Sexing Method. Journal of Animal \& Plant Sciences, 44 (3); 7708-7716. http://www.m.elewa.org/Journals//wpcontent/uploads/2020/06/3.Iswati.pdf
Krautwald-Junghanns, M. E., Cramer, K., Fischer, B., Förster, A., Galli, R., Kremer, F., ... \& Bartels, T. (2018). Current approaches to avoid the culling of day-old male chicks in the layer industry, with special reference to spectroscopic methods. Poultry Science, 97(3), 749-757. https://doi.org/10.3382/ps/pex389

Kuroiwa, A. (2017). Sex-determining mechanism in avians. In Avian Reproduction (pp. 19-31). Springer, Singapore. https://doi.org/10.1007/978981-10-3975-1_2

Mohammadi, H., \& Ansari-Pirsaraei, Z. (2014). Changes in some blood parameters and production performance of old laying hens due to growth hormone and testosterone injection. Journal of Animal Physiology and Animal Nutrition, 98(3), 483-490. https://doi.org/10.1111/jpn.12095

Mohan, J., Sharma, S. K., Kolluri, G., Tyagi, J. S., \& Kataria, J. M. (2015). Selection of Diluent for Short Term Preservation of Guinea Fowl Semen. Asian Journal Animal Veterinary Advance, 10(8), 360364. https://doi.org/10.3923/ajava.2015.360.364

Navara, K. J. (2018). Choosing sexes. Cham, Switzerland: Springer International Publishing. https://doi.org/10.1007/978-3-319-71271-0

Pike, T. W., \& Petrie, M. (2005). Maternal body condition and plasma hormones affect offspring sex ratio in peafowl. Animal Behaviour, 70(4), 745-751. https://doi.org/10.1016/j.anbehav.2004.12.020

Pinson, S. E., Parr, C. M., Wilson, J. L., \& Navara, K. J. (2011a). Acute corticosterone administration during meiotic segregation stimulates females to produce more male offspring. Physiological and Biochemical Zoology, 84(3), 292-298. https://doi.org/10.1086/659373

Pinson, S. E., Wilson, J. L., \& Navara, K. J. (2011b). Elevated testosterone during meiotic segregation stimulates laying hens to produce more sons than daughters. General and Comparative Endocrinology, 174(2), 195-201. https://doi.org/10.1016/j.ygcen.2011.08.020

Reece, W. O., (2009). Functional Anatomy and Physiology of Domestic Animals. 4th edition, Wiley-Blackwell, Ames, Iowa. ISBN-13: 9780813814513

Smith, C. A. (2007). Sex determination in birds: HINTs from the $\mathrm{W}$ sex chromosome?. Sexual Development, 1(5), 279-285. https://doi.org/10.1159/000108934

Susilawati, T. (2014). Sexing Spermatozoa. UB Press. Malang. Indonesia. https://fapet.ub.ac.id/wpcontent/uploads/2017/10/Sexing-spermatozoa-butrinil.pdf 
Tamzil, M., Ni, H., Haryani, K. D., \& Ny, I., Jaya, S. (2018). Polymorphism of Qualitative Traits of Arabic Chicken: A Case Study in Istiqomah Farmer Group, Dasan Cermen, Mataram, West Nusa Tenggara, Indonesia. International Journal of Poultry Science $17 \quad(8) ; \quad 378-384$. https://doi.org/10.3923/ijps.2018.378.384

Wilson, K., \& Hardy, I. C. (2002). Statistical analysis of sex ratios: an introduction. Sex Ratios: Concepts and Research Methods, 1, 48-92. https://doi.org/10.1017/CBO9780511542053.004
Zaghari, M., Taherkhani, R., \& Honarbakhsh, S. (2009). Effects of progesterone injection on performance, plasma hormones and ovarian morphology of ad libitum and restricted fed broiler breeder hens. African Journal of Biotechnology, 8(22); https://doi.org/10.1017/S175275620003043X 